\title{
Representation of Woman Image in Anthology of Poetry "Poetry of Rahim" By the Woman Poet of Five Countries
}

\section{Ika and P. Aditya}

Bahasa Indonesia Education Study Program, STKIP Siliwangi Bandung, Bandung, West Java, Indonesia

\section{Abstract}

Women are interesting figures, superior, and brilliant. No wonder if during the many works of literature that feature images or figures of women like in the anthology of poetry "Poetry of Rahim" by the woman poet of five countries. This article meant to analyze "Poetry of Rahim" with a view to understanding the image of a woman from a woman's point of view and to understanding the image of a woman from

Corresponding Author: M. Ika

Received: 6 April 2018 Accepted: 3 May 2018 Published: 26 July 2018

Publishing services provided by Knowledge

(c) M. Ika and P. Aditya. This article is distributed under the terms of the Creative Commons

Attribution License, which

permits unrestricted use and redistribution provided that the original author and source are credited.

Selection and Peer-review under the responsibility of the ISLLE 2017 Conference Committee.

\section{G OPEN ACCESS} various viewpoints', and societal cultures of Indonesia, Singapore, Malaysia, Brunei Darussalam, and Thailand given that this anthology is composed of poets from these five countries. The method used is a descriptive method with a quantitative form. By using criticism of feminist literature conclusions are drawn regarding the woman image reviewed from a woman's point of view in relation to the relationships with themselves, God, and with other people. Meanwhile the woman image in the understanding and culture of every poet representing their each country have red thread, which suggests that understanding of the mind not only exists in the aesthetic area but also plays an essential role in life.

Keywords: anthology of poetry, poet, woman image

\section{Introduction}

Women are unique figures, interesting, superior, and brilliant, so it is little wonder that many works in the literature have researched women from many perspectives. The study of women in literature first start to surface along with gender issues. The establishment of a women's study center in institutions marks a rise in the number of studies about women.

Strengthening gender issues has a widespread impact on consciousness among literary observers, which is why women for a long time have been marginalized figures. In many ways, women are subordinated. Their position in society is considered lower than that of man. Women are seen as the second sex, the second population, and 
this is also the case in the world of literature. The works of female authors are less calculated, but their work is no less important than the works of male authors. Both traditional works of literature and views about humans in literary works generally reflect an imbalance that marginalizes the role of women [1].

The anthology of poetry "Poetry of Rahim" by women poets from five countries is a way of handling gender issues that developed at that time both in the societal environment and in the literary world. Through this anthology of poetry the women, who come from Indonesia, Singapore, Malaysia, Brunei Darussalam, and Thailand, strive to voice their views on gender awareness. This is voiced by Kartini, an Indonesian female warrior, and the birth of Kartini is the reason why this anthology of poetry was released.

This article aims to reveal the image of women in their relationships with themselves, God, and other people, and also according to minds understanding, and the societal cultures of Indonesia, Singapore, Malaysia, Brunei Darussalam, and Thailand by using feminist criticism of literature.

Literary rationale from a feminist perspective is an attempt to understand the position and role of women as reflected in literary works [2]: 1) the position and role of women figures is still dominated by men; 2) women figures in literary works are left behind men; 3 ) there is a perception that the relationship between men and women is based on mere biological and socioeconomic considerations; 4) the birth of literary research with a feminist perspective; and 5) many consider the role and position of women to be lower than that of man. Those reviews will be reviewed through a study of literature from a feminist perspective.

Feminist literature criticism explained by Culler as the reading as woman. This means the critics view literature by special awareness, and human life. It is caused different views among the creators, readers, and outside factors of the writers and literature readers [2]. Reading as a woman means reading with awareness of unraveling the presumption and ideology of male power, which is patriarchy. The difference of gender in the creator, reader, element of work, and those outside factors which influencing situation of literature communication system. The use of feminism theory is expected to provide new views, especially relating to how the characters are represented in literary works. 


\section{Methods}

The method used to study "Poetry of Rahim" is the descriptive method with a quantitative form. Literary research from a feminist perspective tends to be more based on qualitative research, which places more emphasis on self-interest and certain values. In qualitative research, the feminist perspective towards literary research to get more attention [2].

The resource of this research is the anthology of poetry "Poetry of Rahim [3], which was written by female poets from five countries, i.e. Indonesia, Singapore, Malaysia, Brunei Darussalam, and Thailand. It was released by AWWA publishers in the year 2016, and consists of 139 pages. There are 126 works contributed by 22 writers, all of whom are well-recognized women poets in their each country.

Data were obtained using the listening method (reading) followed by a written technique. The data analysis technique used was content analysis based on feminist theory in litearture research. The stage of studying poetry based on feminist isuue describes various issues related to women from a feminist perspective based on text real.

\section{Results}

\subsection{Woman image in anthology of poetry "Poetry of Rahim" reviewed from woman's point of view}

Depicting the orientation about woman image stacked to problem of life, attitude, and the woman manner with feminism point of view. This study refers to Sitanggang's opinion that the image of women can be divided into three parts, i.e. a woman's relationship with herself, a woman's relationship with God, and woman's relationship with other people [4].

A woman in the current era actually shouldn't change her face. She should be an increasingly tough person, more brilliant, and wiser, even though naturally she has remained the same from the past until now. A woman's image in relationship to herself is a tough figure, eager to work hard, full of consideration, has tough principles, and can solve the problems inside herself. This can be seen in the poetry extract below taken from a work by Enung Nurhayati titled "WHAT WILL BE IS THE WOMAN?"

Dla memikul beban (She bears the burden)

Lebih dari apa yang layak dia pikul (More than what she can bear) 
Memikul tanggungjawab seorang lelaki (Bears the man responsibility)

Lebih dari tenaga lahir maupun bathin dari kodratnya (More than physicality and physiology from her nature)

Other works in the anthology "Poetry of Rahim" featuring the role of a woman as the figure of a mother full with examples of love are "Woman Body" by Fatra Yanuar, "There was a lot of Wind Outside" by Ratna Ayu Budhiarti, "Message for My Son" by Titi Rusmiti, and "There is Orange in Your Eyes" by Elis Tating Badriah. The woman image, besides the role of a mother full of love in terms of caring and taking care of her marriage, also bears responsibility like a man. In here, woman is illustrated as a figure who keeps thinking ahead, is responsible and tough, and fights to improve her fate so she can be appreciated in society. Thus the position that marginalized women will disappear slowly but surely along with the attachment of the role that has been played by women in societal life.

The woman image in relationship to God is that of a woman who always surrenders to God, makes religion the norm as her guidance in life, tries to always be close to God, does everything God says and is always thankful for every blessing given to her. A woman when performing her role in society sometimes faces various problems, and to solve her problems, of course she pleads for God's help to be empowered in finding solutions. The following poems have a religious theme: "Rain in March" by Emy Suy Hariyanto, "Sharing Love" by Faridah Taib, "Sadrah" by Farra Yuniar, "Me, You, and Clamp of Bamboo" by Heni Hendrayani, and "Growing Son of Earth" by Nurhayati. The following extract comes from "GOD PLEASE GUIDE ME' by Nurhayati.

God, Please guide!

It is time to go home fast

Drove to the Ocean

To fight the wave of ignorance

Which often exhousting

The extract above implies the struggle of women in solving a wave of problems that sometimes make them stumble, and for them God is the only place to beg for help. Here it is implied that a woman has the independence to overcome the problems of her life in a rational way. During this time women are stereotyped by society as people who controlled their emotions aspect. This view of course is mistaken.

In her relationship with other humans, the woman image is a figure who is easy to associate with, willing to consult, wise and emphatic, has a loving family, appreciates 
others, and is humble. The following extract from "THERE WAS A LOT OF WIND OUTSIDE" by Ratna Ayu Budiarti illustrates a mother's love for her child, and a mother who loves her family.

Wear your coat

The clatter of the bell is starting to fuss

The wind sign forces the leaves

Fall faster than it should be

Don't you observe the wind sign

Where to go?

They even thought

You are dragged in the same wind direction

\subsection{Woman image in anthology of poetry "Poetry of Rahim" viewed from the understanding of the mind and culture of the women poets of five countries}

Literary works are not born from a culture of emptiness [5]. This means literature mirrors the life of society with the writer, both as an individual who has concepts and ideas in viewing life (the writer) and as a social person who lives in the middle of society. Outline the comprehension of the mind and culture the women poets from five countries conclude that the woman image besides being in the aesthetic region also has an v essential role in life. The poets Anie Din and Faridah Taib from Singapore, Sharahar A. Wahab from Brunei Darussalam, and Pateemah Baa from Thailand expressed this in their works. The extract from "CAN WE (MAMPUKAH KITA)" by the poet Ifa CM from Malaysia refers to women's role in the life of the state.

Your struggle never wasted

All messed up in the face of evil enemies

Fear, brittle mixed with everything

Body and soul offerings

In order to maintain

Mandate of Motherland

The extract above shows that men should change their stereotypical views that declare that women are weak creatures, who can be treated as they please, because 
in some aspects woman can act and struggle the same as men, and even do things men can't do.

Meanwhile, the poet Enung Nurhayati from Indonesia depicts woman figures in aesthetic terms with her poem "YOUR BEAUTY IS HEARTBREAKING." Women are depicted as beautiful and charming figures. Women's charms change to being "heartbreaking" when used as a medium to do something forbidden.

For me

Your beauty is heartbreaking

Womanhood which has everything

Almost per-fect

Perfect

Even what you have

That is dream of other woman

Related to that role, women should struggle in society for the progress of their nation, especially the progress of women themselves. Women and men should be equal. In addition, women should think about how to be modern women who play a role in development. What should the attitude of women be in society and in the future. Women themselves must struggle to improve their lot so they can be appreciated by the society.

Next, the poet Sherly Idris from Malaysia analyzes Mother Kartini. Sherly, through her work, flatters the spirit of Indonesian women heroes in her poem entitled "Mother Kartini: I wrote this poem," and Mother Kartini as a guardian or light carrier for women in her poem "Bed Waste," and the holy intention to improve the fate of women in her poem "If Kartini is Right." Kartini, women come from Mayong village, District Jepara doesn't mean to break the tradition of women's life naturally, but her deep desire to go out from shell of seclusion. The thinking potential of Kartini is much influenced by Stella, a member of a party that fought a lot over humanism, including gender equality. As citizens of Indonesia, we should be proud because gait of Mother Kartini as Indonesian woman emancipation hero cieve ppreciation from the poet from Malaysia.

\section{Conclusion}

Based on the presentation of data analysis, we can conclude that the woman image in the anthology of poetry "Poetry of Rahim" by woman poets from five countries 
consists of three aspects, i.e. the woman image in relationship with herself is drawn as a tough figure, willing to work hard, full of consideration, with tough principles, and can solve the problems inside herself. The woman image in her relationship with God is drawn as a figure who always surrenders to God, makes religion the norm as her guidance in life, tries to be closer herself to God, does everything God says, and is always thankful for every blessing given to her. And the women image in her relationship with other humans is drawn as a figure who is easy to associate with, willing to be consulted, wise and emphatic, has a loving family, appreciates others, and is humble. Meanwhile the woman image according to the thought and culture from the five countries suggests that women also have a role that is essential in life.

\section{References}

[1] Djajanegara, Soenarjati: Kritik Sastra Feminis. Jakarta: PT Gramedia Pustaka Utama; 2000.

[2] Sugihastuti, Suharto: Kritik Sastra Feminis. Yogyakarta: Pustaka Pelajar; 2010.

[3] Bahar E: Perempuan Penyair Lima Negara. Jakarta: Kosa Kata Kita; 2016.

[4] Kasmiati, Elmustian, Rumadi H: Citra Perempuan dalam Novel Habibie dan Ainun Karya Bacharuddin Jusuf Habibie. Skripsi. Universitas Riau, Riau; 2010.

[5] Teeuw A: Membaca dan Menilai Sastra. Jakarta:P.T. Gramedia; 1984. 